\title{
Pengaruh Ekstrak Gulma dan Bahan Alami Terhadap Perkecambahan Jagung
}

\section{Effect of Weed Extract and Naturally Materials on Maize Germination}

\author{
Muji Rahayu^, Amalia Tetrani Sakya, Djoko Purnomo, Aprilia Ike Nurmalasari \\ Department of Agrotechnology, Faculty of Agriculture, Universitas Sebelas Maret, Surakarta, Indonesia \\ *Corresponding author: mujirahayu@staff.uns.ac.id
}

Received: February 25, 2021; Accepted: March 29, 2021; Published: April 1, 2021

\begin{abstract}
The presence of weeds in the crop can become a competitor and reduce crop production. Each type of weed and naturally materials contains different allelochemical compounds. This research aims to create appropriate technology for weed management in maize cultivation, especially in the early growth phase (germination) so that it can suppress the effect of weeds at the beginning of growth and increase maize growth. The research used a completely randomized design (CRD) with 8 treatments namely aquadest (without weed extract/control), extract of the weed in the teki groups (Cyperus rotundus), grass weeds (Dactyloctenium aegyptium) and wide leaf weeds (Euphorbia heterophylla), ketapang, beluntas, acacia, and ginger (Zingiberaceae). The results showed that weed extract of $D$. aegyptium gave the greatest effect of inhibition of germination compared to C. rotundus and E. heterophylla at 12 DAS. Ginger leaf extract (Zingiberaceae) had the greatest effect on inhibition of germination compared to ketapang, beluntas, and acacia on corn seeds at 7 DAS. The application of weed extracts and natural ingredients can have an inhibitory effect, especially on the growth phase, namely the maize germination phase.
\end{abstract}

Key words: allelochemistry; broad leaves; grasses; sedges

Cite this as: Rahayu, M., Sakya, A. M., Purnomo, D. \& Nurmalasari, A. I. (2021). Pengaruh ekstrak gulma dan bahan alami terhadap perkecambahan jagung. Agrosains : Jurnal Penelitian Agronomi, 23(1), 43-49. DOI: http://dx.doi.org/10.20961/agsjpa.v23i1.48952

\section{PENDAHULUAN}

Jagung adalah komoditi strategis bagi Indonesia karena mempunyai dimensi penggunaan yang luas seperti pakan ternak (langsung atau olahan), pangan pokok bagi sebagian penduduk (berpotensi untuk masyarakat yang lebih luas) dan jajanan, bahan baku industri (pati, gula, pangan olahan), dan energi (bioetanol). Separuh dari penggunaan saat ini adalah sebagai bahan baku utama industri pakan ternak. Penggunaan lain meliputi bahan pangan langsung, bahan baku minyak nabati non kolesterol, tepung jagung dan makanan kecil. Pengembangan jagung harus melihat potensi dan struktur kebutuhan tersebut secara komprehensif (Badan Ketahanan Pangan Kementerian Pertanian, 2014).

Salah satu faktor penyebab penurunan produksi dan produktivitas jagung yaitu adanya gulma yang tumbuh di sekitar pertanaman jagung. Gulma adalah tumbuhan yang tidak dikehendaki yang dapat tumbuh di sekitar pertanaman. Gulma merupakan salah satu faktor yang menyebabkan penurunan hasil tanaman jagung. Tanaman sangat peka terhadap persaingan dengan gulma pada periode pertumbuhan sampai berumur kirakira 1 bulan (Mobli et al., 2020; Molinari et al., 2020). Gulma dapat menyebabkan gangguan terhadap tanaman budidaya karena menyebabkan terjadinya persaingan dalam hal unsur hara, air, cahaya, dan ruang tumbuh. Selain itu, gulma dapat pula menyebabkan gangguan karena adanya alelopati (Menalled et al., 2020).

Semua tanaman mampu menghasilkan suatu senyawa alelokimia. Alelokimia dapat menyebabkan penghambatan pertumbuhan tanaman karena mengandung beberapa senyawa seperti golongan fenol, flavonoid yang mana senyawa tersebut berpengaruh pada proses metabolism tanaman (Koodkaew et al., 2018). Untuk mengetahui seberapa efektif alelokimia tersebut dapat dilakukan penelitian dengan mengekstrak berbagai jenis gulma dan bahan alami yang kemudian diberikan pada benih tanaman. Kemampuan alelokimia yang dihasilkan oleh masing-masing tanaman dalam menekan pertumbuhan tanaman lain dan gulma juga beragam sehingga perlu kajian mengenai tingkat efektivitas masing-masing terhadap penekanan pertumbuhan gulma serta terhadap tanaman jagung sendiri. Hasil penelitian Rawat et al., (2012) menunjukkan bahwa beberapa varietas padi menghasilkan senyawa fenolat (vanilat, p-kumarat, ferulat, $p$-hidroksibenzoat) lebih tinggi pada varietas padi lokal dan mampu menghambat komponen pertumbuhan akar, bintil akar, aktivitas nitrogenase pada kedelai dan kacang hijau. Shekoofa et al., (2020) melaporkan bahwa kulit buah jengkol segar mengandung senyawa fenolat, flavonoid dan asam galat serta mempunyai daya hambat lebih tinggi pada bagian akar padi dibandingkan tajuk. 
Alelokimia ini mempunyai hambatan lebih besar pada gulma daun lebar daripada rumputan dan tekian. Hasil penelitian Astutik et al., (2012) menunjukkan pemberian ekstrak daun beluntas (Pluchea indica L.) mengakibatkan perbedaan pertumbuhan gulma meniran (Phyllanthus niruri L.) dan kacang hijau (Phaseolus radiatus L.) pada konsentrasi yang berbeda dan hambatan terbesar pada konsentrasi $2 \%$. Pemberian $2 \%$ ekstrak daun beluntas (Pluchea indica L.) mengakibatkan hambatan pertumbuhan gulma meniran (Phyllanthus niruri L.) dan kacang hijau (Phaseolus radiatus L.). Pemberian ekstrak daun ketapang (Terminalia cattapa) pada konsentrasi $50 \%$ dapat menghambat pertumbuhan gulma rumput teki (Cyperus rotundus) (Riskitavani \& Purwani, 2013).

Belum banyak dilakukan penelitian terkait tingkat keefektifan ekstrak gulma dan bahan alami terhadap pertumbuhan tanaman, sehingga pada penelitian ini mencoba untuk mengetahui tingkat efektifitas masingmasing ekstrak gulma dan bahan alami yang diberikan dalam perkecambahan jagung. Diharapkan pada penelitian ini dapat mengetahui bagaimana tingkat keefektifan berbagai ekstrak gulma dan bahan alami pada pertumbuhan jagung fase perkecambahan. Besarnya konsentrasi ekstrak gulma yang dapat menghambat perkecambahan sangat beragam. Pemberian Ageratum conyzoides konsentrasi 10\% (100 $\mathrm{g} / \mathrm{L}$ ) sudah menghambat perkecambahan sawi, semakin tinggi konsentrasi sampai $30 \%(300 \mathrm{~g} / \mathrm{L})$, penekanan semakin meningkat (Hafsah et al., 2012). Berdasarkan hal itu, besarnya konsentrasi yang diberikan sebesar $12 \%$, karena didasarkan pada penelitian sebelumnya konsentrasi $10 \%$ sudah menghambat. Pemberian sebanyak $3 \mathrm{ml}$ dilakukan berdasarkan percobaan sebelumnya, bahwa pada pemberian ekstrak sebanyak $3 \mathrm{ml}$ sudah cukup untuk membasahi lapisan atau kertas buram yang digunakan sebagai alas petridis dan semua biji yang ada di petridish. Apabila diberikan dengan volume yang lebih sedikit maka tidak semua lapisan dan biji terkena ekstrak, dan apabila lebih dari $3 \mathrm{ml}$ kondisinya terlalu lembab sehingga rentan untuk tumbuh jamur.

\section{BAHAN DAN METODE}

Penelitian dilaksanakan mulai Agustus-November 2020 bertempat di Laboratorium Ekologi dan Manajemen Produksi Tanaman serta Laboratorium Fisiologi Tumbuhan dan Bioteknologi, Fakultas Pertanian UNS Surakarta. Penelitian menggunakan rancangan acak lengkap (RAL) dengan 8 perlakuan yaitu aquades (tanpa ekstrak gulma/kontrol), ekstrak gulma golongan tekian (Cyperus rotundus), gulma rumputan (Dactyloctenium aegyptium) dan gulma daun lebar (Euphorbia heterophylla), ketapang, beluntas, akasia, dan Zingiberaceae. Untuk masing-masing perlakuan diulang 4 kali sehingga untuk penelitian pertama terdapat 32 satuan percobaan.

Alat yang digunakan antara lain petridish, sprayer, oven, penggaris, timbangan digital, pipet, erlemeyer, gelas ukur, alat tulis, kamera, saringan, blender, sedangkan bahan yang digunakan antara lain kertas buram, benih jagung varietas Tambin dan kertas label, $C$. rotundus, $D$. aegyptium, $E$. heterophylla, daun ketapang, daun beluntas, daun akasia, dan daun Zingiberaceae (jahe).
Tahapan pelaksanaan dalam percobaan ini meliputi (a) Persiapan tempat dan peralatan penelitian. Petridish (diameter $15 \mathrm{~cm}$ ) yang akan digunakan dicuci bersih dan dikeringkan. Selanjutnya diberi kertas merang sebanyak 2 lapis. Benih jagung yang akan dikecambahkan (10 biji) diatur dalam petridish; (b) Penyiapan ekstrak gulma dan bahan alami. Metode atau cara yang digunakan dalam ekstrak gulma dan bahan alami mengacu pada metode yang digunakan (Guntoro, 2003) yaitu pertama mengeringkan seluruh bagian gulma dengan oven pada suhu $800 \mathrm{C}$ selama dua hari. Setelah kering kemudian gulma dihaluskan. Gulma tersebut direndam dengan aquadest selama 24 jam. Kemudian dilakukan penyaringan dan air hasil saringan tersebut digunakan sebagai larutan ekstrak dalam perlakuan. Pemberian ekstrak gulma dilakukan dengan cara menyiramkan larutan tersebut sesuai dengan perlakuan ke benih. (d) Pemberian ekstrak gulma dan bahan alami. Aplikasi ekstrak gulma dan bahan alami pada benih jagung dilakukan pada hari pertama pengecambahan benih dan selanjutnya diberikan lagi tiga hari sekali dengan konsentrasi $12 \%$ sebanyak $3 \mathrm{ml}$. (e) Pemeliharaan dan pengamatan. Dilakukan setiap hari dengan mengamati perkembangan benih jagung yang dikecambahkan.

Parameter pengamatan meliputi kecepatan berkecambah, persentase berkecambah, waktu munculnya kecambah, panjang akar, panjang tunas, bobot kering tunas, dan bobot kering akar. Adapun metode yang diguankan pada pengambilan data antara lain: pengamatan Persentase kecambah dan kecepatan kecambah yaitu dengan menghitung jumlah kecambah pada hari ke-n kemudian dibagi semua kecambah yang di kecambahkan dikali 100\%. Waktu munculnya kecambah yaitu diamati ketika benih yang di kecambahkan berkecambah pada waktu atau hari ke berapa. Panjang akar dan Panjang tunas diamati dengan mengukur Panjang akar dan Panjang tunas dengan menggunakan penggaris pada umur 1, 4, 7, 12 dan 14. Bobot kering tunas dan bobot kering akar dihitung setelah kecambah di oven sampai kering dengan suhu $800 \mathrm{C}$ kemudian ditimbang dengan menggunakan timbangan analitik. Semua parameter diamati pada umur 1, 4, 7, 12 dan 14 hari setelah benih dikecambahkan. Data dianalisis dengan analisis keragaman atau Analysis of varian (Anova) dan jika terdapat perbedaan yang nyata dilanjutkan dengan uji jarak berganda DMRT (Duncan Multiple Range Test) dengan tingkat ketelitian 95\%.

\section{HASIL DAN PEMBAHASAN}

Aplikasi beberapa jenis ekstrak gulma dan bahan alami memberikan pengaruh yang berbeda terhadap perkecambahan benih jagung. Hasil pengamatan pengaruh ekstrak gulma dan bahan alami terhadap perkecambahan benih jagung (Tabel 1). Berdasarkan analisis ragam, diketahui bahwa perlakuan pemberian ekstrak gulma $D$. aegyptium, beluntas dan Zingiberaceae (jahe) memberikan pengaruh nyata pada jumlah kecambah jagung dibandingkan dengan perlakuan aquades (tanpa ekstrak gulma/kontrol), hal ini dikarenakan bahwa pemberian ekstrak gulma dan bahan alami menganggu aktivitas perkecambahan benih jagung karena efek alelokimia yang ada pada gulma dan bahan alami tersebut. Berbagai jenis gulma dan bahan alami mengandung senyawa alelokimia yang berbeda- 
beda (Delcheh et al., 2014; Faustino et al., 2019; Zakirov et al., 2021). Adapun masing-masing kandungan senyawa alelokimianya yaitu Beluntas (Pluchea indica L.) merupakan gulma perennial yang diketahui mengandung senyawa alelokemia seperti alkaloid, flavonoid, tannin, dan minyak atsiri yang dapat mempengaruhi perkecambahan biji dan pertumbuhan tanaman disekitarnya, yang dilepaskan ke lingkungan baik dalam bentuk senyawa menguap dari daun maupun dalam bentuk senyawa hasil dekomposisi dalam tanah (Ahanger et al., 2020; Bouyahya et al., 2020).

Tabel 1. Pengaruh Ekstrak Gulma dan Bahan Alami Terhadap Jumlah Kecambah Jagung

\begin{tabular}{lccccc}
\hline \multicolumn{1}{c}{ Perlakuan } & \multicolumn{5}{c}{ Rerata Jumlah Kecambah (buah) } \\
\cline { 2 - 6 } & $\mathbf{1 ~ H S T}$ & $\mathbf{4 ~ H S T}$ & 7HST & $\mathbf{1 2 ~ H S T ~}$ & 14 HST \\
\hline Aquades (tanpa ekstrak gulma) & $6,25 \mathrm{a}$ & $9,00 \mathrm{a}$ & $9,00 \mathrm{a}$ & $9,50 \mathrm{a}$ & $9,75 \mathrm{a}$ \\
Cyperus rorundus & $5,00 \mathrm{a}$ & $9,75 \mathrm{a}$ & $9,50 \mathrm{a}$ & $8,50 \mathrm{a}$ & $8,50 \mathrm{a}$ \\
Dactyloctenium aegyptium & $1,50 \mathrm{c}$ & $7,75 \mathrm{a}$ & $8,00 \mathrm{a}$ & $6,50 \mathrm{~b}$ & $6,50 \mathrm{~b}$ \\
Euphorbia heterophylla & $5,75 \mathrm{a}$ & $9,25 \mathrm{a}$ & $9,00 \mathrm{a}$ & $9,00 \mathrm{a}$ & $8,25 \mathrm{ab}$ \\
Beluntas & $2,00 \mathrm{c}$ & $8,25 \mathrm{a}$ & $8,00 \mathrm{a}$ & $9,00 \mathrm{a}$ & $9,00 \mathrm{a}$ \\
Ketapang & $4,50 \mathrm{ab}$ & $9,00 \mathrm{a}$ & $9,25 \mathrm{a}$ & $8,50 \mathrm{a}$ & $8,75 \mathrm{a}$ \\
Akasia & $6,25 \mathrm{a}$ & $9,25 \mathrm{a}$ & $9,00 \mathrm{a}$ & $8,25 \mathrm{ab}$ & $8,25 \mathrm{ab}$ \\
Zingiberaceae (Jahe) & $3,00 \mathrm{bc}$ & $9,50 \mathrm{a}$ & $8,00 \mathrm{a}$ & $8,75 \mathrm{a}$ & $8,25 \mathrm{ab}$ \\
\hline
\end{tabular}

Keterangan: Angka-angka yang diikuti oleh huruf yang sama pada kolom yang sama menunjukkan berbeda tidak nyata menurut uji Duncan pada taraf $5 \%$.

Teki (Cyperus rotundus L.) merupakan gulma berbahaya yang memiliki kemampuan besar dalam menyerap unsur hara dari dalam tanah sehingga tumbuh menyebar dengan cepat dan menekan tanaman utama (Ebtan et al., 2014). Senyawa fenol sebagai salah satu metabolit sekunder yang terkandung dalam alelokimia teki dapat beragam jenisnya pada bagian dan umur tanaman yang berbeda (Gajger \& Dar, 2021; Islam et al., 2021).

Daun ketapang dapat dimanfaatkan sebagai pengendali gulma karena menghasikan senyawa alelokimia berupa flavonoid, alkaloid, tanin, steroid, resin, saponin. Selain itu, kehadiran flavonoid, terpeniod, steroid, kuinon, tannin dan saponin pada ekstrak daun ketapang ( $T$. catappa) dapat diindikasikan untuk menjadi herbisida nabati (bioherbisida) (Aslam et al., 2017; Riskitavani \& Purwani, 2013). Li et al., (2020) bahwa senyawa alelopati akasia menghasilkan senyawa fenol, femenol, dan alkaloid yang bersifat nonpolar sehingga dapat menghambat perkecambahan biji jagung dan kacang tanah dengan persentase toksisitas pada kontrol perlakuan masing-masing secara berurutan yaitu sebesar $80 \%$ dan $60 \%$.

Rerata jumlah kecambah yang dihasilkan pada perlakuan Dactyloctenium aegyptium pada umur 1 HST sebanyak 1,5 buah yang merupakan rerata terkecil dibandingkan dengan semua perlakuan yang ada. Efek alelokimia dari $D$. aegyptium sudah mulai menghambat pada 1 HST sehingga berdampak pada jumlah kecambah yang dihasilkan. Hal yang sama terjadi ketika umur 12 HST dan 14 HST, perlakuan D. aegyptium memberikan pengaruh nyata dibandingkan dengan semua perlakuan. Alelokimia berpotensi dapat digunakan sebagai pengatur tumbuh, herbisida, insektisida, dan produk perlindungan tanaman antimikroba (Dewi et al., 2017; Fang et al., 2015; Hayat et al., 2018; Rob et al., 2021).

D. aegyptium mengandung berbagai jenis senyawa seperti fenol, flavonoid, steroid, minyak, terpenoid, tannin dan saponin. Dengan adanya berbagai senyawa dari golongan fenol, terpenoid dan flavonoid sehingga memberikan pengaruh alelokimia pada pertumbuhan tanaman. Selain ekstrak $D$. aegyptium, ekstrak jahe
(Zingiberaceae) juga menyebabkan penurunan jumlah kecambah pada umur $14 \mathrm{HST}$. Hal ini sejalan dengan penelitian Isda et al., (2016) bahwa konsentrasi ekstrak daun jahe berpengaruh terhadap indeks vigor tanaman jagung yang menunjukkan penurunan signifikan bila dibandingkan dengan kontrol. Metabolit sekunder utama pada jahe adalah minyak atsiri, suatu campuran senyawa mudah menguap yang kebanyakan tergolong terpenoid (Hegarty et al., 2001). Terpen, yakni hidrokarbon yang dibentuk dari unit isopren (C5), merupakan kelompok terbesar metabolit sekunder tumbuhan (Weston \& Mathesius, 2013). Perlakuan yang mengalami peningkatan jumlah kecambah pada umur 14 HST yaitu pada perlakuan aquades (tanpa ekstrak gulma/kontrol) dan ketapang, hal ini diduga kecambah yang awalnya tidak tumbuh, kemudian tumbuh sehingga jumlah kecambah mengalami peningkatan.

Berdasarkan analisis ragam, menunjukkan bahwa perlakuan aquades (tanpa ekstrak gulma/kontrol) berbeda nyata dengan perlakuan $D$. aegyptium, beluntas dan Zingiberaceae (Jahe) pada 1 HST. Sedangkan pada umur 12 HST dan 14 HST perlakuan aquades (tanpa ekstrak gulma/kontrol) hanya berbeda nyata dengan perlakuan $D$. aegyptium, hal ini berarti bahwa perlakuan ekstrak $D$. aegyptium menunjukkan pengaruh yang signifikan pada Persentase kecambah benih jagung, hal ini mengakibatkan kecambah yang tumbuh menjadi lebih sedikit, selain itu ekstrak $D$. aegyptium memiliki kandungan alelokimia seperti fenol, flavonoid, steroid, minyak, terpenoid, tannin dan saponin yang mana dapat menghambat aktivitas perkecambahan. Pada umur 4 HST dan 7 HST semua perlakuan tidak menunjukkan perbedaan yang nyata, hal ini menunjukkan bahwa pada umur 4 HST dan 7 HST benih jagung mampu beradaptasi sehingga kecambah yang awalnya tidak tumbuh, menjadi mampu tumbuh atau berkecambah.

Persentase perkecambahan adalah perbandingan antara jumlah benih yang berkecambah normal dengan jumlah total benih yang dikecambahkan dikali $100 \%$ (Talukdar, 2011). Persentase perkecambahan menjadi variabel pengamatan karena, pada merupakan variabel yang penting untuk mengetahui jumlah benih yang berkecambah normal, sehingga jika persentase 
kecambah yang tinggi menunjukkan bahwa benih dapat berkecambah baik walaupun diberi ekstrak gulma atau pun bahan alami, sehingga diketahui keefektifan ekstrak gulma dan bahan alami dalam mempengaruhi perkecambahan benih jagung. Tabel 2 menunjukkan bahwa persentase kecambah mengalami peningkatan pada umur $4 \mathrm{HST}$, namun memasuki umur $7 \mathrm{HST}$ persentase kecambah mengalami penurunan kecuali pada perlakuan $D$. aegyptium dan ketapang masingmasing yaitu $80 \%$ dan $92,5 \%$. Penurunan persentase kecambah karena kecambah mengalami kematian karena pengaruh dari pemberian ekstrak gulma dan bahan alami. Penurunan persentase kecambah yang cukup tinggi yaitu pada perlakuan ekstrak jahe (Zingiberaceae) yaitu dari $95 \%$ menjadi $80 \%$. Hal ini menunjukkan bahwa pengaruh alelokimia pada ekstrak jahe cukup besar. Menurut Han et al., (2008) menyimpulkan bahwa antara Ekstrak batang, daun dan rimpang temulawak, ekstrak batang lebih efektif menghambat perkecambahan kedelai dan kucai. Selain itu pada penelitian Ahmed et al., (2020) menemukan bahwa Jatropa curcus merangsang pertumbuhan jagung sedangkan ekstrak jahe menekan pertumbuhan jagung.

Alelokimia dapat mempengaruhi pertumbuhan tanaman yang di tanam berikutnya melalui proses alelopati (Arsa et al., 2020). Menurut Ferreira et al., (2020), alelopati meliputi proses penghambatan maupun perangsangan pertumbuhan dan perkecambahan tanaman yang disebabkan oleh alelokimia yang dilepaskan ke lingkungan oleh suatu tanaman. Pengaruh alelopati tersebut dapat terjadi secara langsung ataupun tidak langsung dari suatu tumbuhan terhadap tumbuhan lain, termasuk mikroorganisme. Alelopati bersifat selektif, yaitu berpengaruh terhadap jenis tanaman tertentu namun tidak terhadap jenis tanaman yang lain. Pengaruhnya lebih terlihat pada tahap kecambah, karena kecambah mempunyai struktur yang belum terdeferensiasi sempurna, mekanisme pertahanan diri belum kuat, dan lebih peka atau mempunyai sensitivitas yang cukup tinggi terhadap senyawa kimia yang dikeluarkan suatu tanaman. Gangguan yang terjadi pada fase perkecambahan akan mempengaruhi proses pertumbuhan selanjutnya.

Perkecambahan juga dipengaruhi konsentrasi kandungan zat terlarut, antara lain adalah alelokimia pada media perkecambahan. Semakin tinggi konsentrasi zat yang terlarut akan menghambat difusi air dan oksigen yang masuk ke dalam biji melalui proses imbibisi. Selain hal tersebut, konsentrasi alelokimia yang tinggi akan mengganggu aktivasi enzim dan hormon yang berperan penting dalam pertumbuhan kecambah. Kemampuan penghambatan senyawa fenol tergantung dari konsentrasinya (Macías et al., 2019; Weston \& Mathesius, 2013).

Pada perlakuan aquades (tanpa ekstrak gulma/kontrol) tetap stabil yaitu sebesar 90\%. Peningkatan pada perlakuan $D$. aegyptium dan Ketapang dikarenakan kecambah yang awalnya belum tumbuh, kemudian tumbuh pada hari ke-7 atau diduga pemberian ekstrak $D$. aegyptium dan ketapang memberikan stimulasi untuk benih jagung dapat berkecambah secara sementara, karena pada umur 12 HST persentase kecambah mengalami penurunan menjadi $82,5 \%$. Hal ini berarti bahwa perlakuan ekstrak gulma dan bahan alami selain menghambat perkecambahan juga dapat menjadi stimulator pada benih jagung untuk berkecambah. Sejalan dengan penelitian Fang et al., (2015) bahwa alelokimia berpotensi dapat digunakan sebagai pengatur tumbuh, herbisida, insektisida, dan produk perlindungan tanaman antimikroba. Pada daun, batang dan rimpang terlihat aktivitas penghambatan lebih banyak ekstrak rimpang karena adanya alelokimia.

Berdasarkan Tabel 1 dan 2, ekstrak beberapa jenis gulma dan bahan alami tidak terlalu berpengaruh terhadap perkecambahan jagung, namun panjang tajuk dan akar yang dihasilkan pada masing-masing perlakuan cukup bervariasi. Hasil pengamatan panjang tajuk dan panjang akar kecambah jagung disajikan pada Gambar 1.

Tabel 2. Pengaruh Ekstrak Gulma dan Bahan Alami terhadap Persentase Kecambah Benih Jagung

\begin{tabular}{|c|c|c|c|c|c|}
\hline \multirow{2}{*}{ Perlakuan } & \multicolumn{5}{|c|}{ Persentase Kecambah (\%) } \\
\hline & 1 HST & 4 HST & 7 HST & 12 HST & 14 HST \\
\hline Aquades(tanpa ekstrak gulma) & $62,5 a$ & $90,0 a$ & $90,0 a$ & $95,0 a$ & $97,5 a$ \\
\hline Cyperus rorundus & $50,0 a$ & $97,5 a$ & $95,0 a$ & $85,0 a$ & $85,0 a$ \\
\hline Dactyloctenium aegyptium & $15,0 \mathrm{c}$ & $77,5 \mathrm{a}$ & $80,0 a$ & $65,0 b$ & $65,0 b$ \\
\hline Euphorbia heterophylla & $57,5 a$ & $92,5 a$ & $90,0 a$ & $90,0 a$ & $82,5 a b$ \\
\hline Beluntas & $20,0 c$ & $82,5 a$ & $80,0 a$ & $90,0 a$ & $90,0 a$ \\
\hline Ketapang & $45,0 a b$ & $90,0 a$ & $92,5 a$ & $85,0 a$ & $87,5 a$ \\
\hline Akasia & $62,5 a$ & $92,5 a$ & $90,0 a$ & $82,5 a b$ & $82,5 a b$ \\
\hline Zingiberaceae (Jahe) & $30,0 \mathrm{bc}$ & $95,0 \mathrm{a}$ & $80,0 \mathrm{a}$ & $87,5 a$ & $82,5 a b$ \\
\hline
\end{tabular}

Keterangan: Angka-angka yang diikuti oleh huruf yang sama pada kolom yang sama menunjukkan berbeda tidak nyata menurut uji Duncan pada taraf $5 \%$.

Berdasarkan Gambar 1, panjang tajuk dan akar yang dihasilkan paling besar pada pemberian aquades (tanpa ekstrak gulma/kontrol). Hal ini menunjukkan bahwa ekstrak gulma dan bahan alami menyebabkan penghambatan pertumbuhan kecambah sehingga tajuk dan akar yang terbentuk juga terhambat pertumbuhannya. Alelokimia dapat mengubah kandungan zat pengatur tumbuh atau menyebabkan ketidakseimbangan dalam berbagai fitohormon, yang menghambat pertumbuhan dan perkembangan tanaman, misalnya dengan sehubungan dengan perkecambahan benih dan pertumbuhan bibit. Paling fenolik alelokimia dapat merangsang aktivitas oksidase IAA dan menghambat reaksi POD dengan IAA, mengikat GA atau IAA untuk mempengaruhi tingkat hormon endogen (Zhou et al., 2020).

Panjang tajuk dan akar paling rendah ditunjukkan pada ekstrak daun jahe (Zingiberaceae) masing masing $1,83 \mathrm{~cm}$ dan $1,49 \mathrm{~cm}$. Hal ini menunjukkan bahwa 
alelokimia yang terkandung dalam jahe mempunyai efek penghambatan paling besar pada benih jagung dibandingkan dengan lainnya. Hal ini dikarenakan alelokimia menghambat pertumbuhan radikula dan bulu kecil di berbagai tanaman dengan menghalangi hidrolisis nutrisi dan pembelahan sel (Oyerinde et al., 2009).

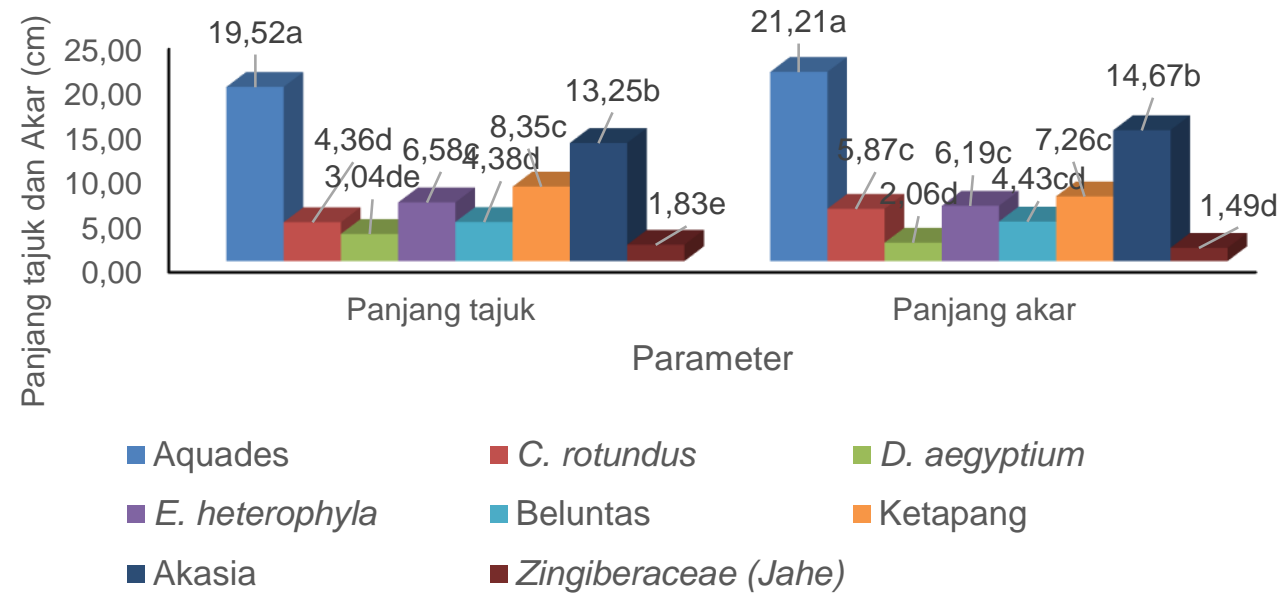

Gambar 1. Panjang tajuk dan Panjang akar kecambah jagung

Keterangan: Angka-angka yang diikuti oleh huruf yang sama menunjukkan berbeda tidak nyata menurut uji Duncan pada taraf $5 \%$.

Bobot segar kecambah dan bobot kering kecambah jagung yang dihasilkan pada setiap perlakuan pemberian ekstrak gulma dan bahan alami juga bervariasi (Gambar 2 dan 3). Gambar 2 dan Gambar 3 menunjukkan bahwa semua benih jagung yang diberikan ekstrak gulma mempunyai bobot segar dan bobot kering kecambah lebih rendah dibandingkan dengan perlakuan aquades (tanpa ekstrak gulma/kontrol). Hal ini menunjukkan bahwa ekstrak gulma dan bahan alami menghambat pertumbuhan kecambah jagung. Pemberian ekstrak gulma $D$. aegyptium dan ekstrak bahan alami (daun jahe/Zingiberaceae) menyebabkan penghambatan paling besar sehingga bobot segar dan bobot kering kecambah yang dihasilkan paling sedikit dibandingkan perlakuan lainnya. Berdasarkan penelitian Han et al., (2008) dalam bobot basah jagung menurun dengan peningkatan konsentrasi ekstrak jahe yang mana konsentrasi pada ekstrak batang, daun dan rimpang jahe bobot segar maksimum tercatat pada konsentrasi $20 \%$ dan berat segar minimum tercatat dalam konsentrasi $100 \%$. Berat segar menurun dengan peningkatan konsentrasi yang mungkin karena adanya alelokimia penghambat pertumbuhan dalam ekstrak daun jahe (Zingiberaceae).

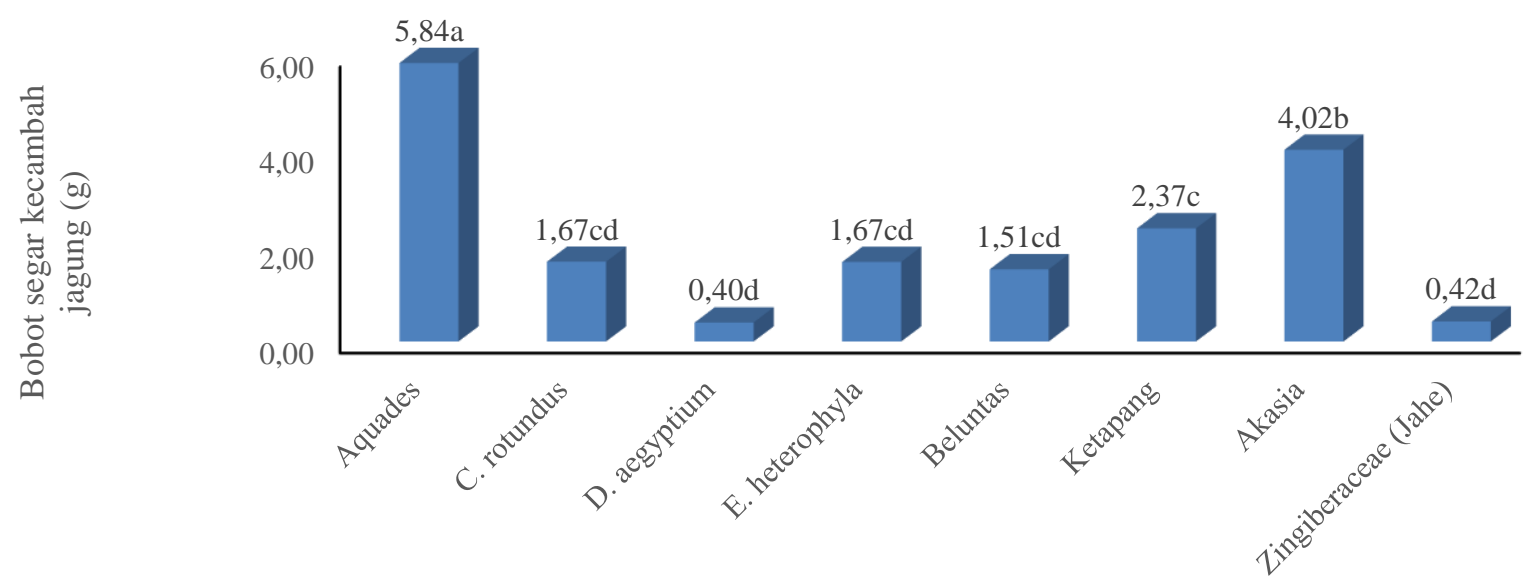

Macam Ekstrak

Gambar 2. Pengaruh ekstrak gulma dan bahan alami terhadap bobot segar kecambah jagung

Keterangan: Angka-angka yang diikuti oleh huruf yang sama menunjukkan berbeda tidak nyata menurut uji Duncan pada taraf $5 \%$. 


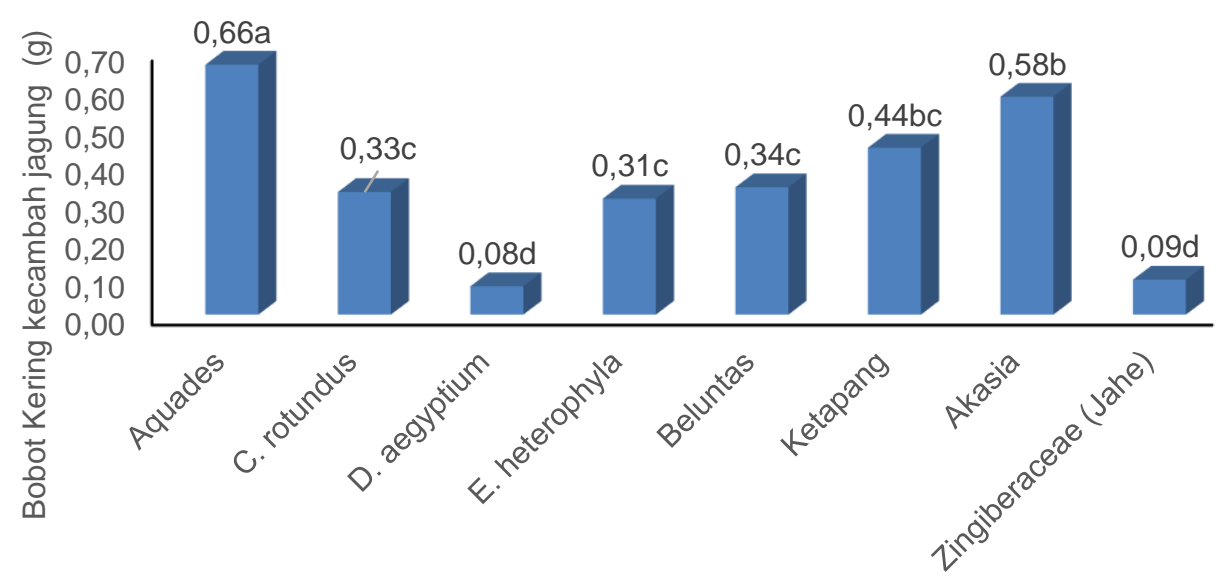

Macam ekstrak

Gambar 3. Pengaruh ekstrak gulma dan bahan alami terhadap bobot kering kecambah jagung

Keterangan: Angka-angka yang diikuti oleh huruf yang sama menunjukkan berbeda tidak nyata menurut uji Duncan pada taraf $5 \%$.

\section{KESIMPULAN}

Ekstrak gulma $D$. aegyptium memberikan pengaruh penghambatan perkecambahan paling besar dibandingkan $C$. rotundus dan E. heterophylla pada 12 HST, sedangkan ekstrak bahan alami yaitu ekstrak daun jahe (Zingiberaceae) memberikan pengaruh penghambatan perkecambahan paling besar pada 7 HST.

\section{DAFTAR PUSTAKA}

Ahanger, M. A., Mir, R. A., Alyemeni, M. N., \& Ahmad, P. (2020). Combined effects of brassinosteroid and kinetin mitigates salinity stress in tomato through the modulation of antioxidant and osmolyte metabolism. Plant Physiology and Biochemistry, 147(September 2019), https://doi.org/10.1016/j.plaphy.2019.12.007

Ahmed, M. I., Xu, X., Sulieman, A. A., Mahdi, A. A., \& Na, Y. (2020). Effect of extraction conditions on phenolic compounds and antioxidant properties of koreeb (Dactyloctenium aegyptium) seeds flour. Journal of Food Measurement and Characterization, 14(2), 799-808. https://doi.org/10.1007/s11694-019-003289

Arsa, A. J. W., Muhamad Achmad Chozin, \& Adolf Pieter Lontoh. (2020). Peningkatan Keefektifan Bioherbisida Berbahan Dasar Umbi Teki dengan Surfaktan dalam Menekan Perkecambahann. Jurnal Agronomi Indonesia (Indonesian Journal of Agronomy), 48(1), 97-103. https://doi.org/10.24831/jai.v48i1.29209

Aslam, F., Khaliq, A., Matloob, A., Tanveer, A., Hussain, S., \& Zahir, Z. A. (2017). Allelopathy in agroecosystems: a critical review of wheat allelopathyconcepts and implications. Chemoecology, 27(1). https://doi.org/10.1007/s00049-016-0225-x

Astutik, A. F., Raharjo, \& Purnomo, T. (2012). Pengaruh Ekstrak Daun Beluntas Pluchea Indica L. terhadap Pertumbuhan Gulma Meniran (Phyllanthus Niruri L.) dan Tanaman Kacang Hijau (Phaseolus Radiatus L.). Jurnal Lentera Bio, 1(1), 9-16.

Badan Ketahanan Pangan Kementerian Pertanian.
(2014). Rencana Strategi Badan Ketahanan Pangan Tahun 2015-2019. http://bkp.pertanian.go.id

Bouyahya, A., Chamkhi, I., Guaouguaou, F. E., Benali, T., Balahbib, A., El Omari, N., Taha, D., El-Shazly, M., \& El Menyiy, N. (2020). Ethnomedicinal use, phytochemistry, pharmacology, and food benefits of Thymus capitatus. Journal of Ethnopharmacology, 259(February), 112925. https://doi.org/10.1016/j.jep.2020.112925

Delcheh, K. S., Kashefi, B., \& Mohammadhassan, R. (2014). A review optimization of tissue culture medium medicinal plant: Thyme. International Journal of Farming and Allied Sciences, 3(9), 10151019.

Dewi, N., Wijayanto, N., \& Gusmaini. (2017). Dimension growth of Azadirachta excelsa and Phyllanthus spp. In agroforestry system. Biodiversitas, 18(2), 494-499. https://doi.org/10.13057/biodiv/d180207

Ebtan, R., Sugiharto, A. N., \& Widaryanto, E. (2014). Ketahanan beberapa varietas jagung manis (Zea mays Saccharata Sturt) terhadap populasi gulma teki (Cyperus rotundus). J. Prod. Tanaman, 1(6), 471477.

Fang, C., Li, Y., Li, C., Li, B., Ren, Y., Zheng, H., Zeng, X., Shen, L., \& Lin, W. (2015). Identification and comparative analysis of microRNAs in barnyardgrass (Echinochloa crus-galli) in response to rice allelopathy. In Plant, Cell and Environment (Vol. 38, Issue 7). https://doi.org/10.1111/pce.12492

Faustino, M. V., Faustino, M. A. F., \& Pinto, D. C. G. A. (2019). Halophytic grasses, a new source of nutraceuticals? A review on their secondary metabolites and biological activities. International Journal of Molecular Sciences, 20(5). https://doi.org/10.3390/ijms20051067

Ferreira, P. H. U., Thiesen, L. V., Pelegrini, G., Ramos, M. F. T., Pinto, M. M. D., \& da Costa Ferreira, M. (2020). Physicochemical properties, droplet size and volatility of dicamba with herbicides and adjuvants on tank-mixture. Scientific Reports, 10(1), 1-11. https://doi.org/10.1038/s41598-020-75996-5 
Gajger, I. T., \& Dar, S. A. (2021). Plant allelochemicals as sources of insecticides. Insects, 12(3), 1-21. https://doi.org/10.3390/insects12030189

Hafsah, S., Ulim, M. A., Cut, D., \& Nofayanti, M. (2012). EFEK ALELOPATI Ageratum conyzoides TERHADAP PERTUMBUHAN SAWI Effects of Allelopathy of Ageratum conyzoides on Mustard Growth. J. Floratek, 8, 18-24.

Han, C. M., Pan, K. W., Wu, N., Wang, J. C., \& Li, W. (2008). Allelopathic effect of ginger on seed germination and seedling growth of soybean and chive. Scientia Horticulturae, 116(3), 330-336. https://doi.org/10.1016/j.scienta.2008.01.005

Hayat, S., Ahmad, H., Ali, M., Hayat, K., Khan, M. A., \& Cheng, Z. (2018). Aqueous garlic extract as a plant biostimulant enhances physiology, improves crop quality and metabolite abundance, and primes the defense responses of receiver plants. Applied Sciences (Switzerland), 8(9). https://doi.org/10.3390/app8091505

Hegarty, M. P., Hegarty, E. E., \& Wills, R. B. H. (2001). Food Safety of Australian Plant Bushfoods (Issue 01). http://www.rirdc.gov.au/reports/NPP/01-28.pdf

Isda, M., Fatonah, S., \& Fitri, R. (2016). Potensi Ekstrak Daun Gulma Babadotan (Ageratum conyzoides L.) terhadap Perkecambahan dan Pertumbuhan Paspalum conjugatum Berg. Al-Kauniyah Jurnal Biologi, 6(2), 120-125. https://doi.org/10.15408/kauniyah.v6i2.2752

Islam, S., Alam, M. B., Ann, H. J., Park, J. H., Lee, S. H., \& Kim, S. (2021). Metabolite profiling of manilkara zapota I. Leaves by high-resolution mass spectrometry coupled with esi and apci and in vitro antioxidant activity, $\alpha$-glucosidase, and elastase inhibition assays. International Journal of Molecular Sciences, 22(1), 1-17. https://doi.org/10.3390/ijms22010132

Koodkaew, I., Senaphan, C., Sengseang, N., \& Suwanwong, S. (2018). Characterization of phytochemical profile and phytotoxic activity of Mimosa pigra L. Agriculture and Natural Resources, 52(2), $162-168$. https://doi.org/10.1016/j.anres.2018.06.005

Li, Y., Xu, L., Letuma, P., \& Lin, W. (2020). Metabolite profiling of rhizosphere soil of different allelopathic potential rice accessions. BMC Plant Biology, 20(1), 1-21. https://doi.org/10.1186/s12870-020-02465-6

Macías, F. A., Mejías, F. J. R., \& Molinillo, J. M. G. (2019). Recent advances in allelopathy for weed control: from knowledge to applications. Pest Management Science, 75(9), 2413-2436. https://doi.org/10.1002/ps.5355

Menalled, U. D., Bybee-Finley, K. A., Smith, R. G., DiTommaso, A., Pethybridge, S. J., \& Ryan, M. R. (2020). Soil-mediated effects on weed-crop competition: Elucidating the role of annual and perennial intercrop diversity legacies. Agronomy, 10(9), $1-15$. https://doi.org/10.3390/agronomy10091373

Mobli, A., Sahil, Yadav, R., \& Chauhan, B. S. (2020). Enhanced weed-crop competition effects on growth and seed production of herbicide-resistant and herbicide-susceptible annual sowthistle (Sonchus oleraceus). Weed Biology and Management, 20(2), 38-46. https://doi.org/10.1111/wbm.12197

Molinari, F. A., Blanco, A. M., Vigna, M. R., \& Chantre, G. R. (2020). Towards an integrated weed management decision support system: A simulation model for weed-crop competition and control. Computers and Electronics in Agriculture, 175(June), 105597.

https://doi.org/10.1016/j.compag.2020.105597

Oyerinde, R. O., Otusanya, O. O., \& Akpor, O. B. (2009). Allelopathic effect of Tithonia diversifolia on the germination, growth and chlorophyll contents of maize (Zea mays L.). Scientific Research and Essays, 4(12), 1553-1558.

Rawat, L. S., Narwal, S. S., Kadiyan, H. S., Maikhuri, R. K., Negi, V. S., \& Pharswan, D. S. (2012). Allelopathic effects of sunflower on seed germination and seedling growth of Trianthema portulacastrum. Allelopathy Journal, 30(1), 11-22.

Riskitavani, D. V., \& Purwani, K. I. (2013). Studi Potensi Bioherbisida Ekstrak Daun Ketapang (Terminalia catappa) terhadap Gulma Rumput Teki (Cyperus rotundus). Jurnal Sains Dan Seni Pomits, 2(2), 23373520.

Rob, M. M., Hossen, K., Khatun, M. R., Iwasaki, K., Iwasaki, A., Suenaga, K., \& Kato-Noguchi, H. (2021). Identification and application of bioactive compounds from garcinia xanthochymus hook. For weed management. Applied Sciences (Switzerland), 11(5), 1-10. https://doi.org/10.3390/app11052264

Shekoofa, A., Safikhan, S., Raper, T. B., \& Butler, S. A. (2020). Allelopathic impacts of cover crop species and termination timing on cotton germination and seedling growth. Agronomy, 10(5). https://doi.org/10.3390/agronomy10050638

Talukdar, D. (2011). Effect of Arsenic-induced Toxicity on Morphological Traits of Trigonella foenumgraecum L . and Lathyrus sativus L . During Germination and Early Seedling Growth. Current Research Journal of Biological Sciences, 3(2), 116123.

Weston, L. A., \& Mathesius, U. (2013). Flavonoids: Their Structure, Biosynthesis and Role in the Rhizosphere, Including Allelopathy. Journal of Chemical Ecology, 39(2), 283-297. https://doi.org/10.1007/s10886-0130248-5

Zakirov, S., Atamirzaev, N., Mukhidova, Z., \& Ziyaev, R. (2021). Secondary plant metabolites as promising pesticides for increasing crop yields. E3S Web of Conferences, 244, 02031. https://doi.org/10.1051/e3sconf/202124402031

Zhou, J., Yang, Q., Zhu, X., Lin, T., Hao, D., \& Xu, J. (2020). Antioxidant activities of clerodendrum cyrtophyllum turcz leaf extracts and their major components. PLOS ONE, $15(6$ June), 1-15. https://doi.org/10.1371/journal.pone.0234435 